Sains Malaysiana 48(9)(2019): 1823-1832

http://dx.doi.org/10.17576/jsm-2019-4809-03

\title{
Analysis and Application of Backfill Mining in Thin Coal Seams for Preventing Building Damage
}

(Analisis dan Aplikasi Perlombongan Kambus Balik dalam Jalur Arang Batu Nipis untuk Mencegah Kerosakan Bangunan)

\author{
ERHu BaI*, WenBing GUO, MiningJie GuO, GAOZHONG LOU \& Yi TAN
}

\begin{abstract}
As coal resources trapped under surface buildings impede the efficient mining of coal seams and constrain the sustainable development of coal mines, a super-high-water backfill mining technique for preventing building damage was adopted. According to the established model of equivalent mining height (EMH), the influence factors were obtained. Afterwards, a measurement to improve the backfill rate was analyzed based on the slurry fluidity. Meanwhile, the relationships between the backfill body compression and its influence factors were studied by numerical simulation. In this way, a more accurate EMH was obtained. To prove this trial practicable, the obtained EMH and the probability integral method were used to predict the surface movement and deformation of the C7401 panel. At the same time, a surface movement observation was set up to observe the mining influence on the surface ground and buildings. The comparison between the predicted and measured data indicated that they corresponded well with each other, the surface movement and deformation values were all controlled within grade I, which protected the surface buildings. Moreover, by applying the super-high-water backfill mining technique, not only building damage has been controlled within Grade I, but the impact on the ecological environment has been reduced also, such as surface subsidence, groundwater leakage and groundwater lowering, which is in harmony with the construction of green mines. The practical trial can provide a reference for mining under similar conditions and is vital for the sustainable development of the mining industry and economic growth.
\end{abstract}

Keywords: Backfill mining; environment protection; overburden movement; surface subsidence; thin coal seam

ABSTRAK

Disebabkan sumber arang batu terperangkap di bawah bangunan permukaan, hal ini menghalang perlombongan arang batu yang cekap dan mengekang pembangunan lestari lombong arang batu, perlombongan secara kambus balik air super-tinggi diterima pakai. Menurut model ketinggian perlombongan setara (EMH), faktor pengaruh diperoleh. Selepas itu, langkah untuk meningkatkan kadar pengisian semula dianalisis berdasarkan kecairan buburan. Sementara itu, hubungan antara mampatan badan pengisian semula dan faktor pengaruhnya dikaji secara terperinci dengan menggunakan simulasi berangka. Dengan cara ini, EMH yang lebih tepat diperoleh. Untuk membuktikan bahawa kaedah ini dapat dijalankan, EMH yang diperoleh dan kaedah integral kebarangkalian digunakan untuk meramalkan pergerakan permukaan dan canggaan panel C7401. Pada masa yang sama, pergerakan permukaan diperhatikan untuk melihat pengaruh perlombongan terhadap permukaan tanah dan bangunan. Berdasarkan perbandingan antara data yang diramalkan dengan yang diukur, ia menunjukkan bahawa mereka bersesuaian antara satu sama lain, iaitu, nilai pergerakan dan canggaan permukaan semuanya dikawal dalam gred I, yang melindungi bangunan permukaan. Lebihlebih lagi, dengan menggunakan perlombongan sumber air super-tinggi, satu siri masalah alam sekitar ekologi yang disebabkan oleh aktiviti perlombongan dapat dikurangkan. Percubaan praktikal boleh digunakan sebagai rujukan untuk perlombongan dalam keadaan yang sama dan sangat penting untuk pembangunan lestari industri perlombongan dan pertumbuhan ekonomi.

Kata kunci: Jalur arang nipis; penenggelaman permukaan; pergerakan tanah beban; perlindungan persekitaran; perlombongan pengisian semula

\section{INTRODUCTION}

China is the world's largest coal producer. With technological and economic development, coal production has grown rapidly from 1.67 Billion tons $(\mathrm{Bt})$ in 2003 to $3.68 \mathrm{Bt}$ in 2018 . China is also a large energy consumer. This is mainly because coal is the primary energy source in China and provides the basis of the energy infrastructure necessary for long-term rapid economic growth (Lin \& Liu 2010). As is well-known, the exploitation of coal resources can lead to a series of environmental problems, such as surface subsidence, farmland reduction, slope instability, and building damage, which is becoming a global problem (Bai et al. 2019; Chen et al. 2019; Hsieh et al. 2011; Rendana et al. 
2017; Xu et al. 2008). Thus, China's '13th Five-Year' plan once again emphasizes that all coal mines should be built in accordance with modernization, green, safety, and ecological requirements. In China, there is an estimated 13.7 $\mathrm{Bt}$ of coal reserves trapped under buildings, water bodies, and railways ('under-three'), among which coal resources under buildings account for 9.5 Bt (Guo \& $\mathrm{Xu}$ 2016). It not only delays efficient mining of coal seams but constrains sustainable development of coal mines, especially for old mining areas, such as, Lvgou coalmine. At present, the coal buried under buildings or other structures in the Lvgou coalmine has reached 2.4 $\mathrm{Mt}$, which greatly shortens its service life and increases the difficulty of subsequent mining activities. Therefore, it is important to adopt a proper mining method to protect the surface buildings and remain in harmony with green mining practices.

In recent years, various mining methods have been applied to control surface subsidence, including strip mining, harmonic mining, room mining and backfill mining (Bai et al. 2018a; Guo et al. 2016; Zhang et al. 2015; Zhao et al. 2004). However, strip mining and room mining have a low mining rate, directly leading to massive coal resources left in the gob, which is a huge waste of coal resources (Sun et al. 2017). Although harmonic mining would achieve the same production as traditional longwall mining method, it cannot control the destruction of the overburden strata. As is well-known, rupture failure of overburden strata is the internal cause of dynamic instability in mining area (Wang et al. 2017). Therefore, to prevent surface building damage and other geological disasters controlling overburden strata is key. By contrast, backfill mining, an important technique in green mining, is a significant revolution in ground control (Bai et al. 2018b). It has been developed to solve the global problems mentioned above, especially in 'under-three' mining, such as hydraulic backfilling, solid backfilling, and high-water material consolidation tailing backfilling (Bell \& Genske 2001; Huang et al. 2011; Kostecki \& Spearing 2015). Moreover, the solid backfill mining method can be used for preventing rock burst and solid waste disposal (Zhang et al. 2014). However, according to the study conducted by Szcepanska and Twardowska (1999), heavy metal pollution caused by mining waste in the backfill mining area can result in groundwater pollution lasting decades, and the pollution intensity increases with time. Moreover, it has already been noted that potential secondary pollution of the underground water quality and underground environment can be caused by solid backfill technology with gangue or waste rock (Bian et al. 2012). To avoid secondary pollution and save the backfill material, super-high-water backfill material has been tested to be 'green' for groundwater by Feng (2009). Therefore, combined with green mining theory, the super-high-water backfill mining method is adopted for mining thin coal seams, which will protect the buildings and is consistent with stable and sustainable production and ecological environmental protection.
In this study, a surface subsidence model for backfill coal mining was established based on the equivalent mining height (EMH) theory. This was followed by the analysis of EMH influence factors. Afterwards, a measure to improve the backfill rate was analyzed based on the slurry fluidity. To obtain a more accurate EMH, the relationships between backfill body compression and its influence factors were studied in detail by numerical simulation. Finally, by taking the C7401 panel of the Lvgou coal mine as an example, the obtained EMH and the parameters of probability integral method were used to predict the surface movement and deformation. The practical engineering case indicated that the measured data corresponded well with the predicted values. In addition, the surface movement and deformation parameters are both controlled within Grade I deformation, protecting the surface buildings and supporting coalmine sustainable development.

\section{GEOLOGICAL CONDITIONS}

Lvgou coal mine is located to the northwest of Xuchang City, Henan province, China, in a field area of $10.33 \mathrm{~km}^{2}$. The current mining coal seam (occurring in the Upper Shihezi Formation of the Permian) has a simple structure. The first trial area is panel C7401, which has a $190 \mathrm{~m}$ width and $760 \mathrm{~m}$ length, located in the eastern mining area. The coal seam ranges from 0.6 to $1.2 \mathrm{~m}$ in thickness, with an average of $0.9 \mathrm{~m}$. Dip angle ranges from 13 to $15^{\circ}$, with an average of $14^{\circ}$. Panel average mining depth is $271 \mathrm{~m}$. The ground surface mainly consists of buildings made of brick and concrete. They all require grade III protection (according to the regulations mentioned in 'Fortification criteria for mining under buildings, water bodies and railways'). The immediate roof and floor are a carbonaceous mudstone with thicknesses of $1.22 \mathrm{~m}$ and $2.6 \mathrm{~m}$, respectively. The location and the buildings in the mining area are shown in Figure 1.

\section{BACKFILL MINING METHOD WITH SUPER-HIGH-WATER MATERIAL BASIC MECHANISM}

Super-high-water backfill mining means two different materials, A and B, are mixed together and transported to the gob area via pipelines. At the same time, the mixed liquid will cure to form the supporting body, resisting the overlying strata and realizing subsidence control. Material A is mainly composed of aluminate or additives while material B consists of gypsum, lime, and clay. Both materials A and B are added into a certain amount of water to make grout. After they are mixed at a ratio of $1: 1$, the setting time of the material could be regulated from 8 to 90 min with different additive contents. Its compressive strength could also be changed under different water contents. For instance, when the water volume content varies between $95 \sim 97 \%$, its final strength varies between $0.66 \sim 1.5 \mathrm{MPa}$ (Zhang et al. 2016). The slurry formed with A or B alone could keep 30 to $40 \mathrm{~h}$ without solidification, whereas the mixture of $\mathrm{A}$ and $\mathrm{B}$ hardens quickly. 


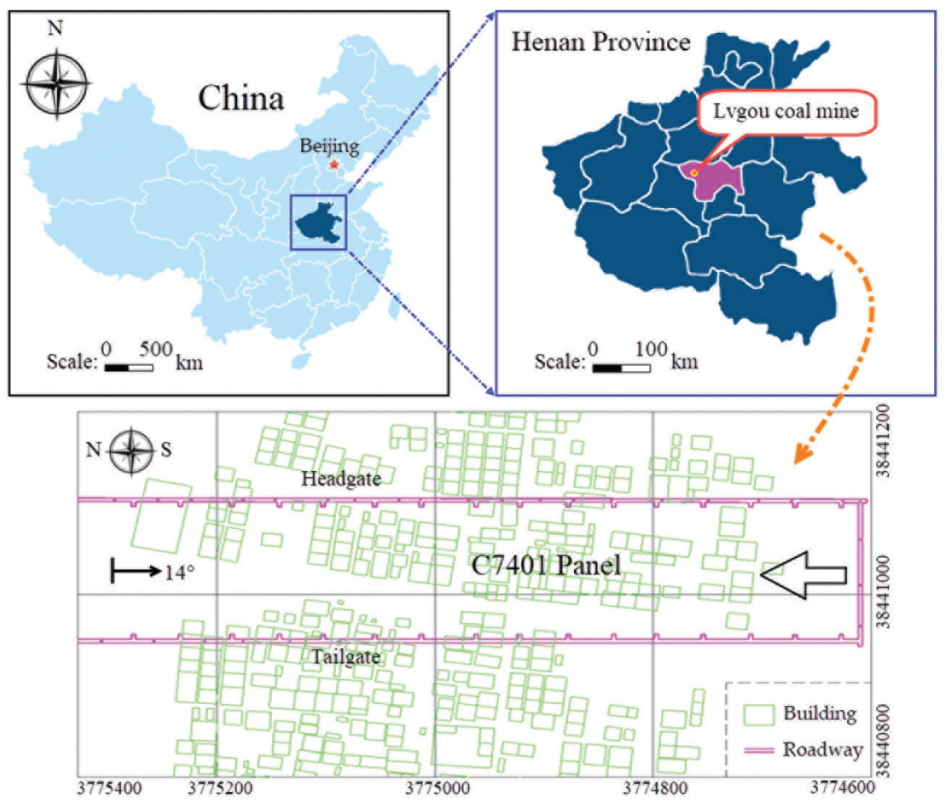

FIGURE 1. The location and buildings in the mining area

\section{MODEL OF BACKFILL MINING TO PREVENT BUILDING DAMAGE}

To reduce surface subsidence, decrease building damage, and improve the coal recovery ratio, the backfill mining method with super high-water material was adopted. The essence of backfill mining reduces the overburden movement by replacing coal resources with backfill material. This method is based on the balance model theory of the strata beam. In this case, a stress balance arch is formed on the top of the gob. The strata self-weight causes the arch to bend and subside. However, as the gob is filled with dense backfill materials, the backfill body achieves a triaxial stress state after compression and becomes part of a supporting body. Then, the overburden strata above the gob gradually become the overburden strata beam due to the backfill body's support. Ultimately, the overburden strata movement is limited to slow bending. Therefore, the surface subsidence can be effectively controlled. This is the principle of backfill mining used to reduce the overburden movement and realize coalmine sustainable production, as well as surface building and ecological environmental protection (Chang et al. 2014).

Backfill mining can be regarded as a method for replacing coal with backfill material. In the gob area, the backfill height after full compression must be lower than the actual mining height, the backfill rate is less than $100 \%$. Therefore, the backfill mining is equivalent to limited thickness extraction, and the unfilled height is the limited thickness. According to the EMH theory for backfill mining (Guo et al. 2014; Miao \& Zhang 2007), the EMH is the height calculated by subtracting the height of the dense backfill body in the gob from the actual mining height. The EMH model was established as shown in Figure 2.

Figure 2 shows the effects of overburden movement and surface subsidence when the actual mining height,

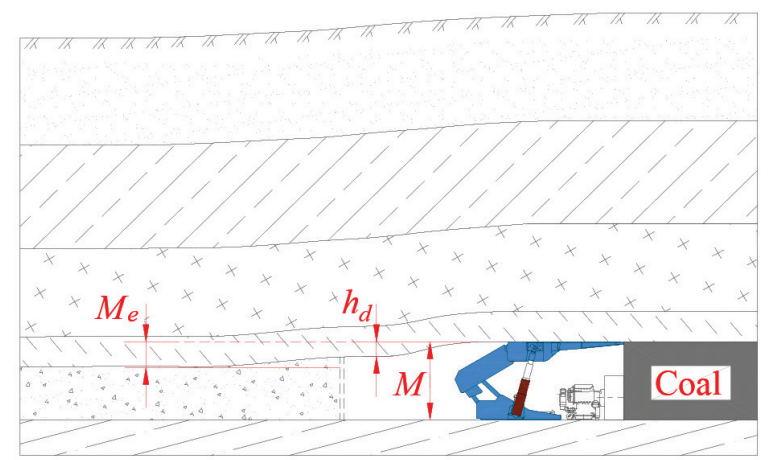

Note: $M_{e}-\mathrm{EMH} ; M$ - mining height; $h_{d}$ - roof-to-floor convergence before backfilling

FIGURE 2. Sketch of the EMH model for backfill mining

$M$, is equivalent to those in the roof caving method, $M_{e}$. Therefore, the EMH is $M_{\mathrm{e}}$. Sometimes, the roof will experience subsidence before backfilling. Consequently, $M_{e}$ consists of two parts, the roof-to-floor convergence of the panel before backfilling and the compression of the backfill body. Therefore, $M_{e}$ can be calculated as shown in (1):

$$
M_{e}=M-\varphi(1-k)\left(M-h_{d}\right)
$$

where $M$ is the actual mining height, $\mathrm{m} ; \varphi$ is the backfill rate; $k$ is the compression rate of the backfill body; and $h_{d}$ is the roof-to-floor convergence of the panel before backfilling, $\mathrm{m}$. The values of $k$ and $\varphi$ are obtained from laboratory tests on the backfill material and field measurements specified by the standard for high water backfilling materials, respectively.

From (1), $M_{e}$ is mainly related to the backfill rate, compression rate, and the roof-to-floor convergence before backfilling. Meanwhile, it has a direct impact on the degree 
of surface subsidence control. For backfill mining under buildings, the maximum $M_{e}$ should be controlled according to surface building criteria to ensure that any surface subsidence that occurs is within an allowable range.

\section{ANALYSIS OF INFLUENCE FACTORS}

As indicated in (1), the backfill rate and the compression rate are closely related to the EMH. Because underground mining is a complicated process, it is necessary to analyze the influence factors of EMH. The analysis of influence factors is as follows:

\section{BACKFILL RATE}

Backfill rate is a key index influencing overburden movement, controlling surface subsidence, and protecting the ecological environment. It represents the actual effect of the gob, as well as reflects the ultimate contact between the backfill body and the roof, and its supporting effect on the overburden strata. Meanwhile, it also directly relates to the control degree of surface subsidence. For the stope with the same backfill conditions, at a higher backfill rate, a smaller void forms in the gob and the smaller activity space of the rock mass. That is, a smaller degree of bending deformation occurs at the top of the base, and there is a better control effect on the rock strata. However, when the backfill rate is low, the mining pressure and strata movement characteristics are similar to the caving method (Zhang et al. 2015). Therefore, the backfill rate is a key index for protecting surface buildings. The inclined coal seam should be adopted longwall topple mining, i.e., the panel advances along the dip direction, as shown in Figure 3.

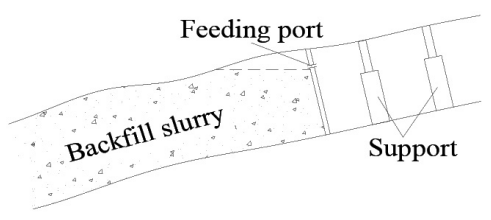

FIGURE 3. Panel advances along the dip direction

As indicated in Figure 3, the gob side behind the panel is low-lying while the backfill port side is high terrain. The enclosure space is easy to form in the gob area, and the sealing requirement on the top of the support side is lower. Moreover, the backfill slurry can automatically flow to the rear gob, and easily achieve a higher backfill rate. This natural advantage can greatly reduce the performance of backfill materials, such as the fluidity, bleeding rate and sealing requirement in gob. Additionally, the backfill process is equivalent to the moving setup room, and the mining process has less influence on the overburden strata. Therefore, the longwall topple mining method is adopted to improve the backfill rate and reduce the EMH value, which realizes surface building and environment protection.

\section{BACKFILL BODY'S COMPRESSION}

To be specific, the backfill body compression mainly includes mining depth, mining height, and overburden strata lithology.

Mining depth As is well known, with different mining depths, the overburden pressure of backfill body is different. The larger the mining depth is, the greater the pressure on the backfill body, and the larger compression strain of backfill body. In other words, the larger mining depth leads to an EMH increase in backfill mining and causes serious surface movement and deformation. According to the close packing theory, the influence on EMH decreases gradually with the increase of mining depth.

Mining height The influence of mining height on $M_{e}$ is mainly due to the increase of mining height and the increase of backfill space. In general, the backfill material will increase with a larger mining height, i.e. there is a positive correlation between the amount of backfill material and mining height. Generally known, the upper backfill body easily slides down and flows during the backfilling process, which results in a lower compaction degree. Therefore, combined with other influencing factors, the mining height is closely related to the backfill rate, and it can be intuitively reflected in the backfill rate.

Overburden strata lithology The overburden strata lithology affects its movement. The harder the rock mass is, the smaller the overburden movement will be. The reason is that the fracture distance of the overburden strata is small when the lithology is soft. Meanwhile, due to the roof fracture, the pressure on the backfill body is large, resulting in significant compression. However, as the overburden strata is hard, its fracture distance is large and the backfill body has enough time to solidify and enhance its strength for supporting overburden strata. Therefore, the compression of the backfill body under hard strata will be smaller than that under soft strata.

\section{NUMERICAL MODELLING}

Numerical simulation can be very good for analyzing the stress and deformation of overburden strata. To further study the influence factors of the backfill body, combined with the actual situation of Lvgou mine, FLAC ${ }^{3 \mathrm{D}}$ software was used to establish the numerical model. The rock strata used in the model have been simplified and the simplified lithologies are, from bottom to top, carbonaceous mudstone, coal seam, carbonaceous mudstone, fine sandstone, mudstone, medium grain sandstone, siltstone, and an unconsolidated layer. The mechanical properties of these lithologies are listed in Table 1. The constitutive model used is the Mohr-Coulomb model.

The model uses a rectangular coordinate system with the $x-y$ directions in the horizontal plane and the $z$-axis in the vertical. The strike of the coal seam is parallel to 
TABLE 1. Mechanical property parameters of model strata

\begin{tabular}{|c|c|c|c|c|c|c|}
\hline Rock type & $\begin{array}{l}\text { Elastic } \\
\text { modulus } \\
(\mathrm{MPa})\end{array}$ & Poisson ratio & $\begin{array}{l}\text { Cohesion } \\
\text { (MPa) }\end{array}$ & $\begin{array}{c}\text { Tensile } \\
\text { strength } \\
(\mathrm{MPa})\end{array}$ & $\begin{array}{c}\text { Internal } \\
\text { friction angle } \\
\left({ }^{\circ}\right)\end{array}$ & $\begin{array}{l}\text { Density } \\
\left(\mathrm{kg} \cdot \mathrm{m}^{-3}\right)\end{array}$ \\
\hline Unconsolidated layer & 150 & 0.30 & 0.10 & 0.00 & 17 & 1900 \\
\hline Siltstone & 21900 & 0.25 & 4.93 & 2.47 & 29 & 2600 \\
\hline Medium grain sandstone & 14500 & 0.23 & 4.12 & 1.96 & 33 & 2630 \\
\hline Mudstone & 6500 & 0.32 & 2.05 & 1.10 & 30 & 2200 \\
\hline Fine sandstone & 16400 & 0.23 & 4.40 & 2.06 & 33 & 2540 \\
\hline Carbonaceous mudstone & 9380 & 0.32 & 2.52 & 1.30 & 30 & 2320 \\
\hline Coal seam & 3300 & 0.33 & 1.20 & 0.64 & 25 & 1440 \\
\hline Carbonaceous mudstone & 9380 & 0.32 & 2.52 & 1.30 & 30 & 2320 \\
\hline
\end{tabular}

the $x$-axis. The model's design simulates a mining panel measuring $190 \mathrm{~m}$ along the strike and $760 \mathrm{~m}$ along the dip of the coal seam. A step-by-step method is used for the simulated excavation. There are 38 excavation steps with each step excavating $20 \mathrm{~m}$. To eliminate boundary effects and replicate actual surface subsidence, $300 \mathrm{~m}$ coal pillars are left on all four sides of the excavated portion. The model size is $1360 \times 790 \times 280 \mathrm{~m}$. Boundary conditions of the model are lateral horizontal displacement constraints, a vertical displacement constraint on the bottom, and a free boundary on the top.

In this case, considering the factors that affect the mining height or EMH, only the mining depth, mining width and lithology are considered. According to the analysis of the influence factors, the single factor analysis method is adopted in the experiment and the panel is mined by using the following mining schemes:

Scheme 1: When the mining height is $1 \mathrm{~m}$ and the backfill rate is $100 \%$, the mining depths are $150 \mathrm{~m}, 200 \mathrm{~m}, 250$ $\mathrm{m}, 300 \mathrm{~m}$, and $350 \mathrm{~m}$, respectively. Scheme 2: When the mining depth is $300 \mathrm{~m}$, the mining height is $1 \mathrm{~m}$, and the backfill rate is $100 \%$, the mining widths are $40 \mathrm{~m}, 80 \mathrm{~m}$, $120 \mathrm{~m}, 160 \mathrm{~m}, 200 \mathrm{~m}$, respectively. Scheme 3: When the mining depth is $300 \mathrm{~m}$, the mining height is $1 \mathrm{~m}$ and the backfill rate is $100 \%$, the lithology of the overburden strata is reduced based on the initial model lithology, and the reduction coefficients are $0.33,0.50,1.00,1.50$, and 2.00 , respectively.

\section{PREDICTION PARAMETERS AND SURFACE MOVEMENT OBSERVATION}

The probability integral method model is based on random medium theory. At present, it has become the most widely used prediction method for mining under buildings and industries (Dai et al.2010; Guo et al.2017; Ma et al. 2017). Many years of practice have shown that the method's precise predictions of surface subsidence can fully meet engineering requirements (Guo 2013). In addition, the EMH probability integral method can be used to predict surface subsidence after backfilling mining. The prediction parameters for surface movement and deformation mainly include the subsidence factor, $q$; tangent of major influence angle, $\tan \beta$; offset distance of inflection point, $s$; influence transference angle, $\theta_{0}$; and horizontal movement factor, $b$. Moreover, they are the primary data for the recovery schemes. During backfill mining under surface buildings, the surface subsidence is closely related to the EMH. Based on the geological and mining conditions, the related surface subsidence prediction parameters are calculated and listed in Table 2.

In addition, to thoroughly study rock strata movement characteristics in the Lvgou coal mine, surface movement observation stations were built in corresponding positions above the panel, and a monthly survey was carried out during the backfilling period. Each observation station consists of a series of interconnected observation points. According to the topographic conditions above the panel, the strike observation line was set up along the village road, denoted Z1 to Z18. Similarly, the dip direction observation line was arranged along the farmland or road, named N1 to N29. The crossing point of the two lines was Nz. The control points were buried next to the roadside out of the mining impact.

In order to analyze the influence of super-high-water backfill mining on the buildings, two mining schemes have been designed to recover the coal resource trapped under the buildings. The schemes are: backfill and caving mining. The surface movement and deformation of two mining methods are analyzed in the results and analysis section.

\section{RESULTS AND ANALYSIS}

\section{MEASURES TO IMPROVE THE BACKFILL RATE AND ROOF SEPARATION MONITORING}

During backfill mining, the initial mining process parameters are as follows: the mining cycle and the caving distance is $1 \mathrm{~m}$, and the backfill cycle is $2 \mathrm{~m}$, i.e. 'two mining one backfilling' (two cutting for each backfilling). Currently, the maximum control distance of the panel is 4.2 $\mathrm{m}$, and the minimum is $3.2 \mathrm{~m}$. In addition, the maximum control distance of the machine head and tail is $5.2 \mathrm{~m}$, and the minimum is $4.2 \mathrm{~m}$. Because the immediate roof is a 1.22 $m$ thick carbonaceous mudstone with fissure development, it collapses immediately after the pillar is withdrawn. Meanwhile, the coal seam is thin, and the collapsed roof 
TABLE 2. Parameters of probability integral method for surface subsidence

\begin{tabular}{ccccc}
\hline $\begin{array}{c}\text { Subsidence } \\
\text { factor }\end{array}$ & $\begin{array}{c}\text { Tangent of major } \\
\text { influence angle }\end{array}$ & $\begin{array}{c}\text { Offset distance of } \\
\text { inflection point }\end{array}$ & $\begin{array}{c}\text { Influence transference } \\
\text { angle }\end{array}$ & $\begin{array}{c}\text { Horizontal movement } \\
\text { factor }\end{array}$ \\
\hline 0.72 & 2.2 & 0 & $81.6^{\circ}$ & 0.3 \\
\hline
\end{tabular}

seriously affects the flow path of the super-high-water slurry in the gob, with a backfill rate of only $66 \%$. However, the key to backfill mining is to ensure an adequate backfill rate. Hence, the backfill process is changed from 'two mining one backfilling' to 'one mining one backfilling' (one cutting for each backfilling) to improve the backfill rate, i.e. the backfill cycle is changed to $1 \mathrm{~m}$. After implementation, although the backfill rate increases, there is roof collapse in many areas, and the backfill space is difficult to maintain effectively before backfilling. To reduce roof collapse and improve the backfill rate, the end row pillar technology used to overhang the cantilever beam and protect the roof is adopted based on 'one mining and one backfilling', as shown in Figure 4. Therefore, the roof at the side of the gob is basically no longer falling, the backfill space is effectively maintained, and the backfill rate increases to $85 \%$. Then, it can be calculated that $\phi$ is $85 \%$.

To monitor the roadway roof separation under the supporting bolt, 17 monitoring points were arranged along the transportation roadway and return air roadway, respectively. The roof separation indicator was installed in the middle of the roadway, the deep base point was anchored to $300 \mathrm{~mm}$ in the stable rock layer above the anchor, and the shallow base point was fixed at the end of the anchorage.

According to the monitoring data, the separation values of the transportation roadway inside and outside the anchorage range are 1 11 $\mathrm{mm}$ and $0 \sim 7 \mathrm{~mm}$, respectively. For the return air roadway, they are $0 \sim 12 \mathrm{~mm}$ and $0 \sim 9$ $\mathrm{mm}$, respectively. The roof anchorage is in good condition, and the roof deformation is controlled effectively, which maintains the integrity of the roof strata. Meanwhile, the maximum parameter $h_{d}$ in (1) is $20 \mathrm{~mm}$.

\section{NUMERICAL SIMULATION RESULTS AND ANALYSIS}

To illustrate the relationship among the influence factors, Figure 5 is constructed from schemes 1 to 3. Figure 5(a) is constructed from scheme 1 to illustrate the relationship between mining depth $H$ and backfill body compression rate $k$; Figure 5(b) illustrates the influence of the mining panel width on the backfill body compression from scheme 2; Similarly, Figure 5(c) shows the lithology influence of overburden strata on the backfill body compression from scheme 3 . The results are as follows.

As shown in Figure 5(a), during backfill mining with super-high-water material, the mining depth has a positive linear correlation with the backfill body compression. That is, the backfill body compression increases with the increase of the mining depth. The relationship between mining depth $H$ and backfill body compression rate $k$ is shown in Figure 5. When the mining depth is $150 \mathrm{~m}$, the backfill body compression rate is 0.010 . Currently, the stress of overburden strata is small, and the pressure on the backfill body is also small. With the increase of mining depth, the pressure of the overburden strata on the backfill body increases, which increases the backfill body compression. Therefore, when the mining depth increases from 150 to $350 \mathrm{~m}$, the backfill body compression rate increases to 0.025 .

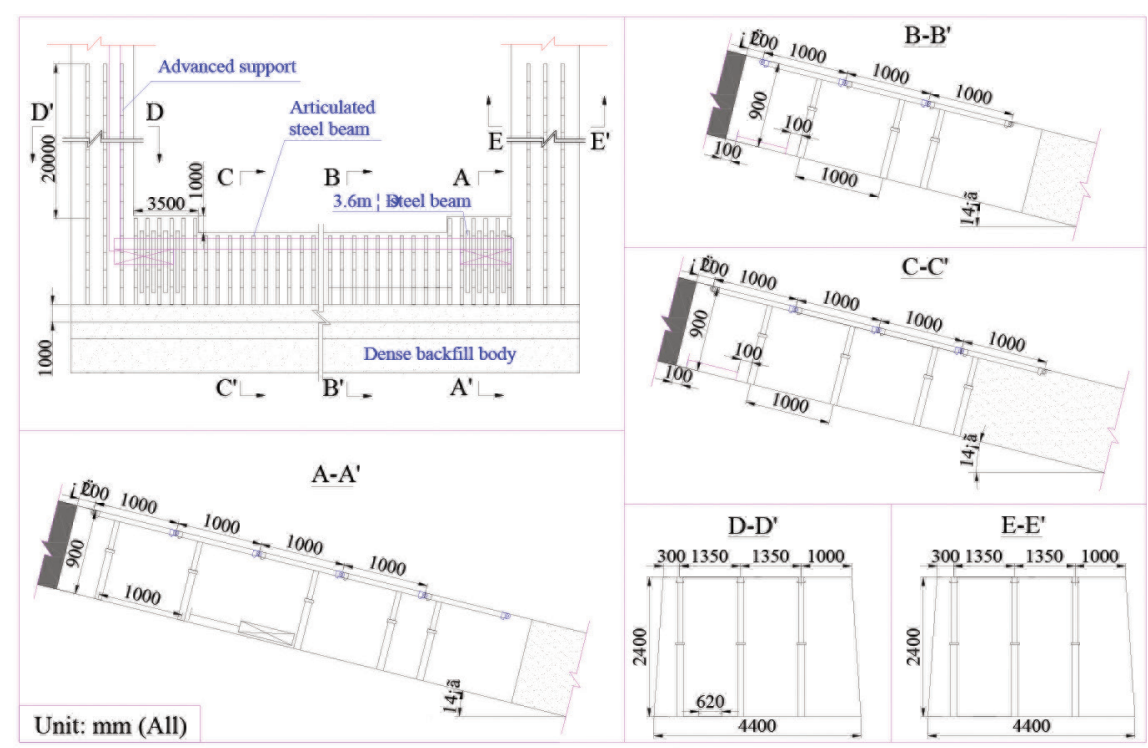

FIGURE 4. Support pattern of super-high-water backfill mining 


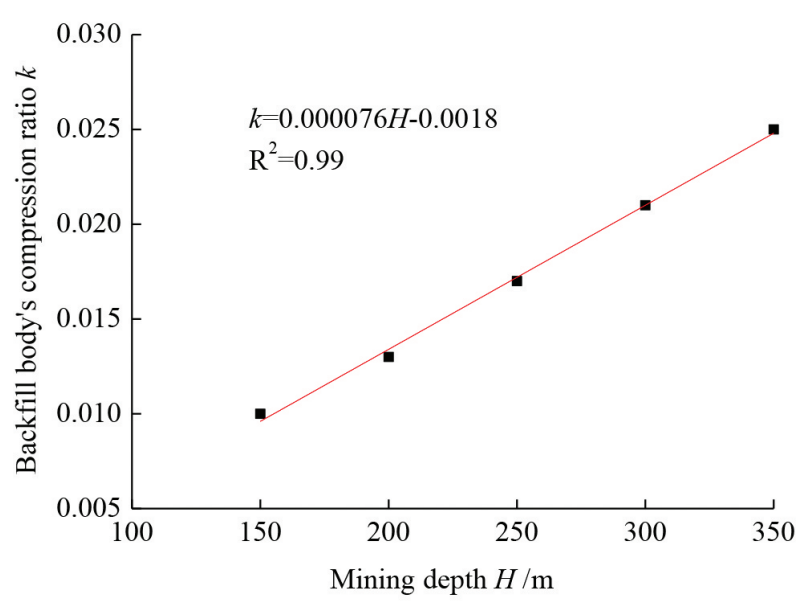

FIGURE 5a. Relationship between the mining depth and backfill body compression rate

As indicated in Figure 5(b), the mining width has a logarithmic relationship with the backfill body compression. When the mining width increases, the backfill body compression also increases. The backfill body compression rate is 0.023 as the mining width is $40 \mathrm{~m}$. This is because the coal pillar is great support to the overburden strata, while the backfill body only bears a small part of the load. Besides, due to the limited load of the coal pillar, the load of the backfill body becomes larger and larger as the mining width increases. Then, the compression rate increases to 0.097 as the mining width is $200 \mathrm{~m}$.

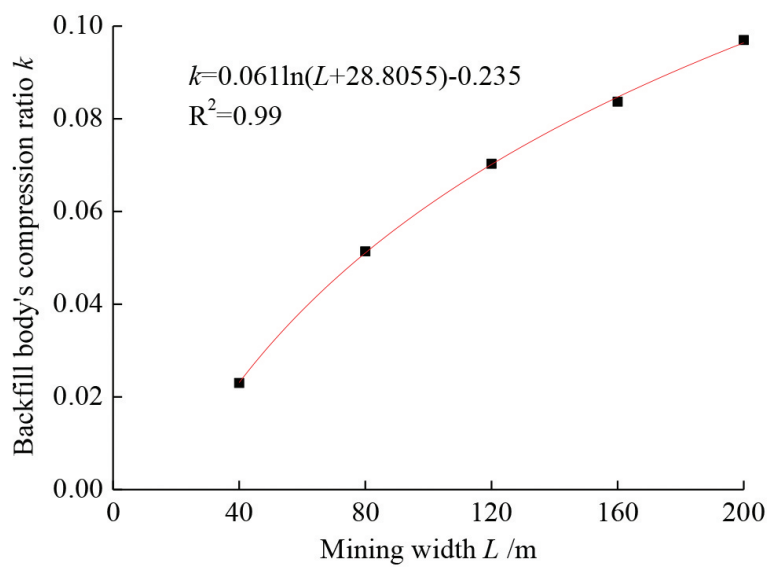

FIGURE 5 b. Relationship between the mining width and backfill body compression rate

From the Figure 5(c), the backfill body compression gradually decreases when the reduction factors of the rock properties increase from 0.33 to 2.00 , which is in accordance with the logarithmic relationship. When the reduction factor is 0.33 , the backfill body compression rate is 0.111 . At this moment, the overburden strata lithology is weak, leading to it becoming broken continuously. Meanwhile, the supporting effect of the coal pillar on the overburden strata is weakened, resulting in great pressure on the backfill body, resulting in a large compression of the backfill body. The overburden strata lithology is hard when the reduction factor is 2.00 , and the backfill body compression is 0.037 , which decreases by $66.7 \%$.

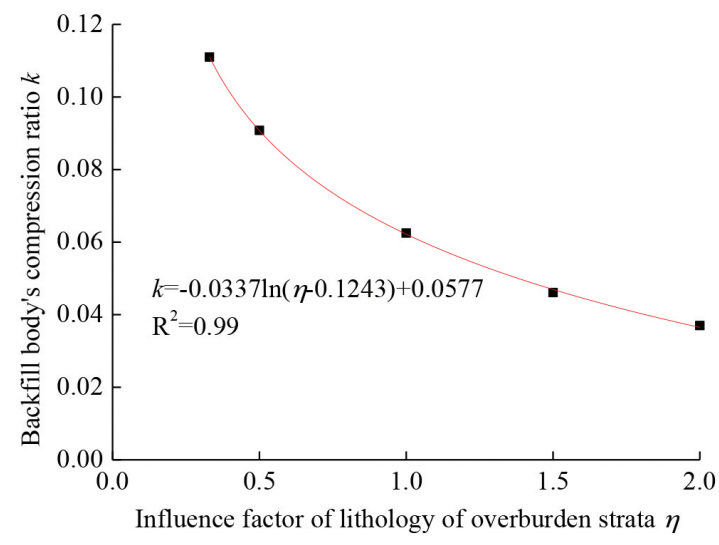

FIGURE 5c. Relationship between lithology influence factor and backfill body compression rate

Therefore, according to the above analysis and parameters, the maximum value of the backfill body compression rate, $k$ is 0.1 .

\section{PREDICTION PARAMETERS AND SURFACE SUBSIDENCE}

The probability integral method is also used to calculate the surface movement and deformation for using the backfill mining and caving methods. From the analysis, it can be determined that $M_{e}$ is $0.2268 \mathrm{~m}$ from formula (1). Meanwhile, $M_{e}$ provides a basis for a more accurate prediction of the surface subsidence. Table 3 lists the maximum values of surface movement and deformation for the two mining methods based on the criteria of 'underthree'.

Based on the prediction data, the maximum surface subsidence above the panel is $580.4 \mathrm{~mm}$ when caving mining is adopted. However, it is only $115.7 \mathrm{~mm}$ when using backfill mining, which is reduced by $80.1 \%$. For caving mining, the maximum surface slope is $4.2 \mathrm{~mm} \cdot \mathrm{m}^{-1}$ and the maximum horizontal deformation is $4.0 \mathrm{~mm} \cdot \mathrm{m}^{-1}$, which exceeds the criterion of Grade II for buildings. For backfill mining, they are both reduced to $0.7 \mathrm{~mm} \cdot \mathrm{m}^{-1}$, which are decreases of $83.3 \%$ and $82.5 \%$. Certainly, the surface ground and buildings are controlled within Grade I. From the comparison, it can be found that super-high-water backfill mining can greatly reduce the surface movement and deformation, effectively reducing the damage grade of buildings and preserving them for safe use.

In addition, real-time monitoring of surface subsidence was conducted by using an observation station. Surface movement observing occurred over 1 year. Because the subsidence of each observation points on the strike line is less than $10 \mathrm{~mm}$, the observation point is considered to 
TABLE 3. Maximum values of surface movement and deformation

\begin{tabular}{lcccc}
\hline Mining method & $\begin{array}{c}\text { Surface subsidence } \\
(\mathrm{mm})\end{array}$ & $\begin{array}{c}\text { Surface slope } \\
\left(\mathrm{mm} \cdot \mathrm{m}^{-1}\right)\end{array}$ & \multicolumn{2}{c}{$\begin{array}{c}\text { Horizontal deformation } \\
\left(\mathrm{mm} \cdot \mathrm{m}^{-1}\right)\end{array}$} \\
\hline Backfill mining & 115.7 & 0.7 & -0.7 & 0.3 \\
Caving mining & 580.4 & 4.2 & -4.0 & 2.0 \\
\hline
\end{tabular}

be within the safety range. Because the longwall topple mining method is adopted in the panel, the subsidence in the dip direction is larger than the strike. The curve of accumulated surface subsidence can be seen in Figure 6.

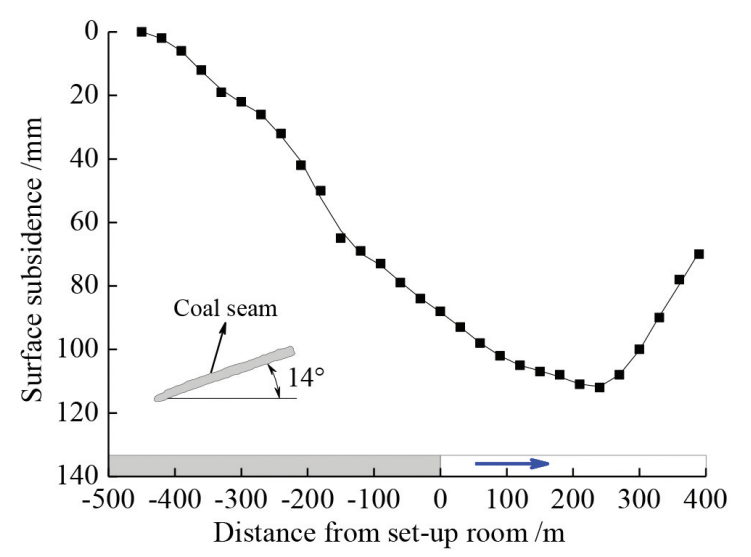

FIGURE 6 . The accumulated surface subsidence in the incline direction

According to the analysis of the surface monitoring data, with the advance of the C7401 panel, the subsidence of each observation points increases gradually. However, the accumulated maximum subsidence at the surface monitoring point is $112 \mathrm{~mm}$ and the maximum horizontal deformation is $0.5 \mathrm{~mm} \cdot \mathrm{m}^{-1}$. These are both controlled within Grade I deformation. Meanwhile, according to the field investigation, the surface ground and buildings exhibit no obvious deformation after the implementation of the super-high-water backfill method, indicating that the goals of protecting the surface buildings and sustainable development are achieved.

In summary, when the super-high-water backfill method is adopted in the Lvgou coal mine, the overburden strata of the gob are well-supported, preventing strata movement and surface subsidence, thereby protecting the ecological environment at the local mining area. Successful application of the super-high-water backfill method may provide some references to mining thin coal seams under buildings or other structures and supporting coal mine sustainable development while protecting the buildings and environment.

\section{SOCIAL AND ECONOMIC BENEFITS ECONOMIC BENEFITS}

Before using the backfill method for a thin coal seam, coal resources are all trapped under the surface buildings. If the caving mining method is adopted, the damage grade of most surface buildings (a total of 650 households in 2 villages) will be Grade II. According to the local compensation price, the coal profits are not enough to compensate for the damaged buildings. However, if it is not exploited, the mine will be closed with no other available resources. By taking the C7401 panel as an example, the mined coal resource using the super-highwater backfill mining method will not only maintain the current production, $1.9 \times 10^{5}$ tons, but also protect the surface buildings from the mining damage. The details are listed in Table 4. Additionally, after the super-high-water backfill mining method is applied under all of the surface buildings and other structures, the mined coal resource can increase by $2.4 \times 10^{6}$ tons for a better economic benefit.

\section{SOCIAL AND ENVIRONMENTAL BENEFITS}

The super-high-water backfill mining of the thin coal seam has extended the mine's service life, which not only promotes local economic development, but also provides certain jobs and increases local income. It can also provide some references for mining thin coal seams under buildings or other structures, which can promote the development of social science and technology. For the environmental damage, the backfill mining method has a smaller environmental impact than the caving mining method, and it also causes less damage to groundwater resources and buildings. The implementation of this method can maintain the ecological balance, therefore, the production and living environment of the local enterprises and surrounding residents will not deteriorate, i.e. the environmental benefits are better.

TABLE 4. Economic benefit comparison of different mining methods in the C7401 panel

\begin{tabular}{lcccc}
\hline Mining method & Recovery ratio & $\begin{array}{c}\text { Production } \\
\left(10^{5} \mathrm{t}\right)\end{array}$ & $\begin{array}{c}\text { Damage grade } \\
\text { of buildings }\end{array}$ & $\begin{array}{c}\text { Benefits } \\
\text { (Million Yuan) }\end{array}$ \\
\hline Backfill mining & $100 \%$ & 1.94 & $\mathrm{I}$ & 11.32 \\
Caving mining & $100 \%$ & 1.94 & II & -0.86 \\
\hline
\end{tabular}




\section{CONCLUSION}

For surface buildings protection and sustainable production of Lvgou coal mine, the super-high-water backfill mining method for extracting the thin coal seam under surface buildings was analyzed and applied on the C7401 panel. The main conclusions of this study were:

According to the analysis of the backfill mining model, the caving zone is not generated in the overburden strata after super-high-water backfill mining. Most are in the bending zones and only few areas are fracture zone, i.e., the strata structures are continuous. Therefore, the Mohr-Coulomb model is chosen as the constitutive model in the numerical simulation.

Based on the EMH theory, the influence factors are analyzed. The backfill rate increases from $71 \%$ to $85 \%$ after the implement of 'one mining one backfilling', meanwhile, the relationships between the backfill body compression and mining depth, mining width, and overburden strata lithology are obtained by numerical simulation. During the actual mining process, the basis and guarantee are provided for the accurate determination of EMH and surface subsidence.

The maximum surface subsidence is $112 \mathrm{~mm}$ and the maximum horizontal deformation was $0.5 \mathrm{~mm} / \mathrm{m}$ after adopting the backfill coal mining method, which is basically the same as that obtained by using the probability integral method. Meanwhile, the surface buildings are both controlled within Grade I as specified by the Coal Industry Criterion, which indicates that the integrity of the overburden is competent. Therefore, this practice has proven effective in terms of controlling the geoenvironmental hazards and extending the mine's service life, which is vital for the sustainable development of the mining industry and economic growth.

\section{ACKNOWLEDGEMENTS}

The authors gratefully acknowledge the financial support for this work provided by the National Natural Science Foundation of China (Grant No. 51774111 and U1810203), Open Fund of State Key Laboratory of Water Resource Protection and Utilization in Coal Mining (Grant No. GJNY-18-76.13) and the Innovation and Outstanding Talent Project of Henan Province Science and Technology (Grant No. 184200510003).

\section{REFERENCES}

Bai, E.H., Guo, W.B. \& Tan, Y. 2019. Negative externalities of high-intensity mining and disaster prevention technology in China. Bulletin of Engineering Geology and the Environment. https://doi.org/10.1007/s10064-019-01468-4.

Bai, E.H., Guo, W.B., Tan, Y. \& Yang, D.M. 2018a. Green coordinated mining technology of strip mining roadway backfilling method. Journal of China Coal Society 43(S1): 21-27.

Bai, E.H., Guo, W.B., Tan, Y. \& Yang, D.M. 2018b. The analysis and application of granular backfill material to reduce surface subsidence in China's Northwest coal mining area. Plos ONE 13(7): e0201112.

Bell, F.G. \& Genske, D.D. 2001. The influence of subsidence attributable to coal mining on the environment, development and restoration: some examples from western Europe and South Africa. Environmental \& Engineering Geoscience 7(1): 81-99

Bian, Z.F., Miao, X.X., Lei, S.G., Chen, S.E., Wang, W.F. \& Struthers, S. 2012. The challenges of reusing mining and mineral-processing wastes. Science 337: 702-703.

Chang, Q.L., Chen, J.H., Zhou, H.Q. \& Bai, J.B. 2014. Implementation of paste backfill mining technology in Chinese coal mines. The Scientific World Journal 2014: 821025.

Chen, S.Z., Lai, G.T., Han, L. \& Tovele, G.S.V. 2019. Effects of tectonic stresses and structural planes on slope deformation and stability at the Buzhaoba Open Pit Mine, China. Sains Malaysiana 48(2): 317-324.

Dai, H.Y., Lian, X.G., Liu, J.Y., Liu, Y.X., Zhou, Y.M., Deng, W.N. \& Cai, Y.F. 2010. Model study of deformation induced by fully mechanized caving below a thick loess layer. International Journal of Rock Mechanics \& Mining Sciences 47(6): 1027-1033.

Feng, G.M. 2009. Research on the super-high water packing material and filling mining technology and their application. Ph.D. Thesis, China University of Mining and Technology, Xuzhou (Unpublished).

Guo, W.B. 2013. Mining Damage and Protection. China Coal Industry Publishing House: Beijing, China.

Guo, G.L., Zhu, X.J. \& Zha, J.F. 2014. Subsidence prediction method based on equivalent mining height theory for solid backfilling mining. Transactions of Nonferrous Metals Society of China 24(10): 3302-3308.

Guo, W.B. \& Xu, F.Y. 2016. Numerical simulation of overburden and surface movements for Wongawilli strip pillar mining. International Journal of Mining Science and Technology 26(1): 71-76.

Guo, W.B., Bai, E.H., Tan, Y. \& Yang, D.M. 2017. Surface movement characteristics caused by fully-mechanized top coal caving mining under thick collapsible loess. Electronic Journal of Geotechnical Engineering 22(3): 1107-1116.

Guo, W.J., Wang, H.L. \& Chen, S .J. 2016. Coal pillar safety and surface deformation characteristics of wide strip pillar mining in deep mine. Arabian Journal of Geosciences 9(2): 1-9.

Huang, Y.L., Zhang, J.X.,Zhang, Q. \& Nie, S.J. 2011. Backfilling technology of substituting waste and fly ash for coal underground. Environmental Engineering and Management Journal 10(6): 769-775.

Hsieh, C., Shih, T., Hu, J., Tung, H., Huang, M. \& Angelier, J. 2011. Using differential SAR interferometry to map land subsidence: A case study in the Pingtung Plain of SW Taiwan. Natural Hazards 58(3): 1311-1332.

Kostecki, T. \& Spearing, A.J.S. 2015. Influence of backfill on coal pillar strength and floor bearing capacity in weak floor conditions in the Illinois Basin. International Journal of Rock Mechanics and Mining Sciences 76: 55-67.

Lin, B.Q. \& Liu, J.H. 2010. Estimating coal production peak and trends of coal imports in China. Energy Policy 38(1): 512-519.

Ma, C.Q., Li, H.Z. \& Zhang, P.P. 2017. Subsidence prediction method of solid backfilling mining with different filling ratios under thick unconsolidated layers. Arabian Journal of Geosciences 10: 511. 
Miao, X.X. \& Zhang, J.X. 2007. Analysis of strata behavior in the process of coal mining by gangue backfilling. Journal of Mining \& Safety Engineering 24(4): 379-382.

Rendana, M., Rahim, S.A., Idris, W.M.R., Lihan, T. \& Rahman, Z.A. 2017. Soil erosion assessment in Tasik Chini Catchment using remote sensing and GIS techniques. Sains Malaysiana 46(4): 529-535.

Sun, Q., Zhang, J.X., Zhang, Q. \& Zhao, X. 2017. Analysis and prevention of geo-environmental hazards with highintensive coal mining: A case study in China's Western ecoenvironment frangible area. Energies 10(6): 786.

Szcepanska, J. \& Twardowska, I. 1999. Distribution and environmental impact of coal mining wastes in upper Silesia, Poland. Environmental Geology 38(3): 249-258.

Wang, X.L., Qin, Q.R. \& Fan, C.H. 2017. Failure characteristic and fracture evolution law of overburden of thick coal in fully mechanized sub-level caving mining. Sains Malaysiana 46(11): 2041-2048.

Xu, S.Y., Shen, S., Cai,Z.Y. \& Zhou, G.Y. 2008. The state of land subsidence and prediction approaches due to groundwater withdrawal in China. Natural Hazards 45(1): 123-135.

Zhang, J.X., Deng, X.J., Zhao, X. \& Li, B.Y. 2016. Effective control and performance measurement of solid waste backfill in coal mining. International Journal of Mining, Reclamation and Environment 31(2): 91-104.

Zhang, J.X., Zhang, Q., Sun, Q., Gao, R., Germain, D. \& Abro, S. 2015. Surface subsidence control theory and application to backfill coal mining technology. Environmental Earth Sciences 74(2): 1439-1448.

Zhang, J.X., Jiang, H.Q., Deng, X.J. \& Ju, F. 2014. Prediction of the height of the water-conducting zone above the mined panel in solid backfill mining. Mine Water and the Environment 33(4): 317-326.

Zhang, Z.Y., Feng, T.T. \& Meng, H.M. 2015. Discussion on the method for determination of compression ratio of filling body with strip mining. The Chinese Journal of Geological Hazard and Control 26(3): 101-106.
Zhao, B.Z., Yu, X.Y. \& Yin, S.X. 2004. Method of reducing damage for bolting overlying strata and harmonic extraction under buildings. Journal of Xian University of Science \& Technology 24(1): 5-8.

Erhu Bai*, Wenbing Guo, Miningjie Guo \& Yi Tan

School of Energy Science and Engineering

Henan Polytechnic University

454000 Jiaozuo, Henan

China

Erhu Bai*, Wenbing Guo \& Yi Tan

State Key Laboratory of Water Resource Protection and Utilization in Coal Mining

102211 Beijing

China

Erhu Bai*, Miningjie Guo \& Yi Tan

Synergism Innovative Centre of Coal Safety Production in Henan Province

454000 Jiaozuo, Henan

China

Gaozhong Lou

School of Civil and Architectural Engineering, Anyang Institute of Technology

455000 Anyang, Henan

China

*Corresponding author; email: 111502010003@home.hpu.edu.cn

Received: 6 November 2018

Accepted: 1 June 2019 